\title{
Core Self-Evaluation and Sales Performance of Female Salespeople in Face-to-Face Channel
}

\author{
Duk Woon YOON', Bo Young KIM², Sung Ho $\mathrm{OH}^{3}$ \\ Received: February 24, 2020 Revised: March 08, 2020 Accepted: April 03, 2020
}

\begin{abstract}
This study seeks to empirically analyze the effects of core self-evaluation and adaptive selling behavior on sales performance for female salespersons engaged in door-to-door sales through the face-to-face channel in the wellness industry. This study seeks to examine the importance of adaptive selling, through, salespeople derive appropriate strategies in response to market changes. For female salespeople who use face-to-face channels, this study empirically investigated the relationship between core self-evaluation and adaptive selling, and effects on sales performance. A 31-item survey was constructed, based on prior research. We selected six door-to-door sales companies in South Korea and conducted one-to-one interviews with female salespeople in the Seoul metropolitan area and analyzed 208 pieces of significant data. Results demonstrated that among the core self-evaluation factors for female salespeople, self-esteem, self-efficacy, and neuroticism had an effect on adaptive selling factors, while locus of control did not. These factors were found to affect sales performance through the mediating role of adaptive selling. Improvements in the adaptive selling capabilities of female salespeople in charge of face-toface channels positively affected sales performance. Management efforts are required to enhance self-esteem, self-efficacy, or neuroticism. These results suggest that companies should support enhancing individual adaptive selling capabilities of their salespeople.
\end{abstract}

Keywords : Face-to-Face Sales, Female Salesperson, Door-to-Door Sales, Core Self-Evaluation, Adaptive Selling Behavior

JEL Classification Code: M12, M39, M53, O15

\section{Introduction}

According to the Korea Direct Selling Industry Association (2017), the domestic door-to-door sales market reached approximately KRW14 trillion, a 3.8\% annual growth rate. Many women are active in door-to-door sales after gaining employment, a representative channel of faceto-face channel sales. (Door-to-door sales is defined as the sale of goods or services to a consumer by a person who makes a direct visit to the consumer.) Door-to-door sales

${ }^{1}$ First Author. PhD Candidate, Seoul Business School, aSSIST, South Korea. Email: eduketer@naver.com

${ }^{2}$ Corresponding Author. Associate Professor, Seoul Business School, aSSIST, South Korea [Postal Address: 46 Ewhayeodae-2-gil,

Seodaemun-gu, Seoul, Korea, 03767] Email: bykim2@assist.ac.kr

${ }^{3}$ Research Professor, The Institute for Industrial Policy Studies,

South Korea. Email: multiosh@gmail.com

(c) Copyright: The Author(s)

This is an Open Access article distributed under the terms of the Creative Commons Attribution Non-Commercial License (http://Creativecommons.org/licenses/by-nc/4.0/) which permits unrestricted noncommercial use, distribution, and reproduction in any medium, provided the original work is properly cited. have consistently increased, and since 2013, a variety of door-to-door sales techniques have been introduced, with corresponding sales generated (Chakrabarty, Brown, \& Widing, 2013). In today's "smart" era, numerous companies are turning to door-to-door sales in the face of a long-term recession. In addition to its traditional fields such as food and cosmetics, door-to-door sales is gaining attention across various industries, with recent inroads being made through virtual currency payments via social network services (SNS) (Homburg, Wieseke, \& Bornemann, 2009).

Through direct connections with customers at point of contact, salespeople can quickly identify customer needs and personal styles and utilize a variety of information about the customer to provide products and services that meet (or surpass) their expectations. This role of salespeople, thus, can ultimately lead to excellent sales performance, in addition to increasing customer satisfaction (Brown, Mowen, Donavan, \& Licata, 2002; Peppard, 2000). In today's sales climate, in which automation of the market economy has led to intensified competition among firms, and little differentiation among products, salespeople can play an important role representing the company. Furthermore, 
for companies that primarily operate door-to-door sales as an important channel, salespeople do more than just sell products; as company representatives, they play a key role delivering both the company's products and image to customers (Swan, Bowers, \& Richardson, 1999).

In particular, relational switching costs, which are important for door-to-door sales-based companies, are linked to continuous use intention. Door-to-door sales, a form of service based on the face-to-face channel with the goal of one-to-one customer engagement, involves daily or regular meetings with customers to exchange products and services. These frequent exchanges can forge a bond of intimacy, and this emotional dimension is gradually becoming more important in the "smart" era (Jones, Mothersbaugh, \& Beatty, 2002). In this respect, by using door-to-door sales services rather than expending time and effort to form relationships by establishing new channels, companies can maintain continuous relationships with customers who desire psychological stability. Given this context, it is helpful for companies to enhance customer-oriented, adaptive selling behavior that emphasizes point of contact with customers (Stock \& Hoyer, 2005; Lee \& Kim, 2019).

Adaptive selling behavior helps establish long-term relationships; it involves focusing on customers' needs and desires, designing products to meet these needs, collecting knowledge about customers, communicating the customers' needs and demands to the company, and developing products and company knowledge (Narver \& Slater, 1990; Nguyen \& Nguyen, 2017). Recent studies have shown that adaptive selling is an important behavior of salespeople in a relational sales environment, thereby affecting individual sales performance (Keillor, Parker, \& Pettijohn, 2000). Researchers have introduced studies on adaptive selling and customeroriented selling that show these selling behaviors are formed by the characteristics of the organization and the psychological characteristics of the individual salesperson, and directly impact sales performance (Vink \& Verbeke, 1993; Jaramillo, Ladik, Marshall, \& Mulki, 2007). However, research is still insufficient on customer-oriented selling and adaptive selling in the door-to-door sales market; very few studies examine the many female door-to-door salespeople who lead face-to-face channel sales (Sprio \& Weitz, 1990; Arfah \& Putra, 2019).

As claimed by Jaramillo et al. (2007), this study argues that the personal and psychological characteristics of salespeople are important to improve customer-oriented selling, and demonstrates empirically how this is related to adaptive selling. By investigating female salespeople in the wellness industry, this study analyzes the relationship of sales performance mediated by adaptive selling based on core self-evaluation. To sum up, this study discusses differentiated sales management strategies that influence the customer-oriented selling of female salespeople, with specific implications for generating strong performance.

\section{Theoretical Background and Hypothesis}

\subsection{Customer-Oriented Selling}

Shapiro (1988) regards the concepts of customer orientation and market orientation as the same; however, market orientation is generally divided into customers, competitors, and the entire organization, whereas customer orientation is a marketing-organization-centric concept focused on the customer (Kohli \& Jaworski, 1994). Saxe and Weitz (1982) defined customer orientation as "the degree to which salespeople practice marketing concepts so that customers can make a satisfactory purchase decision." Thus, even if salespeople with high customer orientation perform actions to increase customer satisfaction and enhance sales in the short term, they exhibit tendencies to avoid behaviors that conflict with the customer's interests (Saxe \& Weitz, 1982).

Prior studies focused on customer-oriented selling identified the individual factors impacting the field as gender, length of service, age, personality, and direction of motivation or purpose (Yeo, Cho, \& Lee, 2017). Parasuraman (1987) proposed organizational climate as a factor affecting customer-oriented selling, such as delegation for problem solving or providing an environment in which colleagues can collaborate; previous literature has also emphasized the importance of creating an environment (Kelley, 1992) that stimulates motivation and organizational culture. Researchers have also argued that customer-oriented selling can ultimately achieve consumer satisfaction (Homburg et al., 2009) when knowledge of customer needs is enhanced, such as competence control and self-control (Jeong, Ahn, \& Lee, 2017), behavioral control (Anderson \& Oliver, 1987), and activity control and outcome control (Jeong et al., 2017).

Since the 1960s, researchers have investigated what is needed to enhance salespeople's performance and to sell effectively, and numerous studies have demonstrated that this performance can be improved through monetary compensation such as incentives and wage increases (Shaw, Brown, \& Bromiley, 1998), and excellent benefits (Kotler, Armstrong, Saunders, \& Wong, 1996), as well as non-monetary compensation such as increased training and communication (Rust, Zahorik, \& Keiningham, 1995). However, research has indicated that salespeople without the disposition or traits to provide good customer service are likely to experience negative phenomena like burnout or emotional dissonance (Adelmann, 1995; Cordes \& Dougherty, 1993). In this respect, consistent with the claim that monetary or non-monetary compensation alone has limited effectiveness in enhancing sales performance, recent studies on effective selling have focused on concepts including adaptive selling and customer-oriented selling. 
Customer-oriented selling is behavior in which salespeople influence the purchasing decisions of the customer at the point of contact. Meanwhile, adaptive selling is the modification of communication style and content and selling behavior when interacting with customers to suit the customers' needs, based on the ability of the salesperson to change his or her selling behavior (Weitz, 1981), or the information related to the nature of the sales situation (Spiro \& Weitz, 1990; Weitz, Sujan, \& Sujan, 1986). Furthermore, customer-oriented selling has become a vital concern for numerous companies that utilize face-to-face sales as an important channel centered on door-to-door interactions. As online shopping has gained prominence worldwide, communication methods for consumers have also changed in the door-to-door sales market, due to demands for high levels of information, attractiveness, and purchasing influence. Thus, suitable communication and sales capabilities are required to identify and meet the needs of these sophisticated customers (Burnham, Frels, \& Vijay, 2003).

In particular, consumers in Asian countries prefer faceto-face channels, emphasizing the bond between individuals, since these consumers highly value the connection felt when sharing information on health and education with salespeople. They also value the emotional aspect of product selection. Therefore, companies must enhance their door-todoor sales organizations and evolve services as consumers themselves evolve, and the importance of customer-oriented selling is magnified (Lee, 2014).

\subsection{Core Self-evaluations and Adaptive Selling Behavior}

Today's rapidly changing sales environment has compelled companies to devote more attention to the human aspect of sales in order to improve sales performance; the passive salesperson no longer contributes to the organization's performance (Kim, 2007). Among previous studies on the conventional salesperson, many examined external factors such as incentives, wage increases, and the knowledge of salespeople. The successful customer service behaviors of salespeople, which are related to their individual disposition or traits, involve the high likelihood of being considerate to customers and adapting to their needs (Taylor, 1983).

Companies are focusing on stimulating sales through salespeople to sell their products effectively (Spiro \& Weitz, 1990). Core self-evaluation refers to the emotional state in which an individual subconsciously evaluates himself or herself and others (Judge, Locke, \& Durham, 1997); a positive self-evaluation indicates the individual's ability to influence the surrounding environment by controlling and adapting to it (Hobfoll, Johnson, Ennis, \& Jackson, 2003).

Core self-evaluation has been described with four characteristics: self-esteem, in which individuals highly evaluate their own abilities and positively believe in themselves; generalized self-efficacy, in which individuals perceive themselves to be successful in a variety of situations; locus of control, in which individuals believe they can positively control the external environment; and neuroticism, which measures the individual's degree of psychological stability (Bono \& Judge, 2003). These four characteristics focus on individuals' fundamental evaluations of themselves. Individuals with high core selfevaluation actively respond to changes in sales strategies and simultaneously utilize them as opportunities to acquire new knowledge or skills (Judge, Erez, Bono, \& Thoresen, 2003; Wanberg \& Banas, 2000). Previous literature has identified, as a cause of failure, companies implementing changes at the organizational level in pursuit of competitive advantages without considering the individual characteristics of the organization's members (Bray, 1994). In this context, the most important factor for salespeople to improve performance is research and development of individual characteristics.

Recently, among these key characteristics of highperforming salespeople, the importance of adaptive selling behavior has been emphasized (Boorom, Goolsby, \& Ramsey, 1998; Robin et al, 2002; Chakrabarty, Brown, Widing, \& Taylor, 2004). In door-to-door sales, where sales are made through the face-to-face interactions with customers, salespeople may develop their ability of persuasion, based on their accumulated experiences, and then apply this knowledge to future sales opportunities, which is an example of learning-based adaptive selling behavior (Park \& Deitz, 2006). On the other hand, selling to all customers with the same methods often leads to mistakes, and makes it difficult to satisfy each customer's needs (Humphrey \& Ashforth, 1994). Because of these findings researchers have argued that not only monetary but also non-monetary factors should be balanced when judging the true level of sales performance (Bucklin \& Sengupta, 1993).

Door-to-door sales, which began in the cosmetics industry in 1962, has evolved into a variety of channels, including sponsorship door-to-door sales (referred to as new door-to-door sales and authentic door-to-door sales), direct sales, multi-level sales, and network sales. Korean door-to-door sales activity is characterized by detailed explanations of the products desired by customers to persuade them to make a purchase, followed by inducing customers to repurchase by forming personal relationships. As such, adaptive selling behavior between salespeople and customers in the face-to-face sales channel of door-to-door sales can be an important factor directly related to sales performance. Based on these previous studies, this study formulates the hypotheses that the core self-evaluation of female salespeople who use face-to-face channels will affect their adaptive selling behavior. 
H1: Among the factors of core self-evaluation, the selfesteem of female salespeople who use face-to-face channels will positively affect their adaptive selling behavior.

H2: Among the factors of core self-evaluation, the selfefficacy of female salespeople who use face-to-face channels will positively affect their adaptive selling behavior.

H3: Among the factors of core self-evaluation, the locus of control of female salespeople who use face-toface channels will positively affect their adaptive selling behavior.

H4: Among the factors of core self-evaluation, the neuroticism of female salespeople who use face-toface channels will positively affect their adaptive selling behavior.

\subsection{Adaptive Selling Behavior and Sales Performance}

Salespeople who sell goods or services at the customer point of contact represent the company and are responsible for communicating the company's image to customers (Swan \& Nolan, 1985). In face-to-face channels, salespeople play a critical role in persuading customers to purchase their products or services through face-to-face meetings and securing prospective customers (Kwak, Anderson, Leigh, \& Bonifield, 2019). Market researchers in previous studies have described adaptive selling behavior as one of the single most important factors of successful salespeople.

Industrial psychology researchers first argued the theoretical basis for adaptive selling behavior (Walker, Churchill, \& Ford, 1977). Adaptive selling refers to a salesperson's ability to change his or her selling behavior based on fundamental information about the sales situation (Weitz, 1981). Salespeople face various consumer buying behaviors when conducting sales activities, which requires their ability to change sales behavior to suit consumer needs. Generally, when sales situations are varied and unpredictable, the level of adaptive selling behavior increases, whereas when sales situations are predictable, the level of adaptive selling behavior decreases (Chakrabarty et al., 2013).

Salespeople can successfully achieve sales by forming long-term relationships with customers through adaptive selling behavior (Park \& Deitz, 2006). The salesperson's ability to respond to situations acquired through his or her experience is important to sales performance and customer relations (Szymanski, 1988). A key feature of adaptive selling behavior is modifying one's actions to an effective sales technique when interacting with customers (Baldauf \& Cravens, 2002). Accordingly, when it comes to strengthening adaptive selling behavior, the company must effectively control and manage its salespeople to enhance sales performance through adaptive selling (Lee \& Ji, 2014); hence, salespeople require organizational training to obtain necessary personal competences and improve expertise.

Since adaptive selling behavior can enhance selling ability, and satisfy customers more effectively than other marketing methods, it has been extensively studied in the B2B field (Saxe \& Weitz, 1982; Kim, Lee, \& Lee, 2009). The ultimate goal of salespeople is to generate strong sales performance. The ability of salespeople to respond adeptly to customers, and to form effective relationships, is directly linked to sales performance because it affects organizational performance (Anderson \& Oliver, 1987). Ultimately, adaptive selling behavior plays a vital role in sales and customer acquisition; it is crucial for service companies to build relationships with customers to contribute to the company's overall business performance (Bitner, Booms, \& Tetreault, 1990).

When salespeople who use face-to-face channels interact directly with customers at the point of contact, they gradually grow in importance (Solomon, Surprenant, Czepiel, \& Gutman, 1985). Among the theories describing factors impacting sales performance, characteristics theory describes the kinds of personality traits required to achieve high performance (Oke, Cohen, Carr, Cromer, Dingizian, Harris, \& Miller, 1995). Specifically, the salesperson should be able to change their sales behavior while communicating with the customer, recognize and build effective marketing strategies for different sales situations, and facilitate the collection of information about purchase changes (Spiro \& Weitz, 1990). This adaptive selling behavior of salespeople in face-to-face channels helps to sustain relationships by addressing dissatisfaction with customers (Franke \& Park, 2006). Based on these previous studies, this study formulates the hypothesis that the adaptive selling behavior of female salespeople who perform door-to-door sales will affect sales performance.

H5: The adaptive selling behavior of female salespeople who use face-to-face channels will positively affect sales performance.

\section{Research Methods and Materials}

\subsection{Research Model}

This study sought to empirically analyze the effects of core self-evaluation and adaptive selling behavior on sales performance for female salespersons engaged in door-todoor sales through the face-to-face channel in the wellness industry. The research model was established based on the above hypotheses to examine sales management implications driven by psychological and dispositional differences in female salespeople. The independent variables 


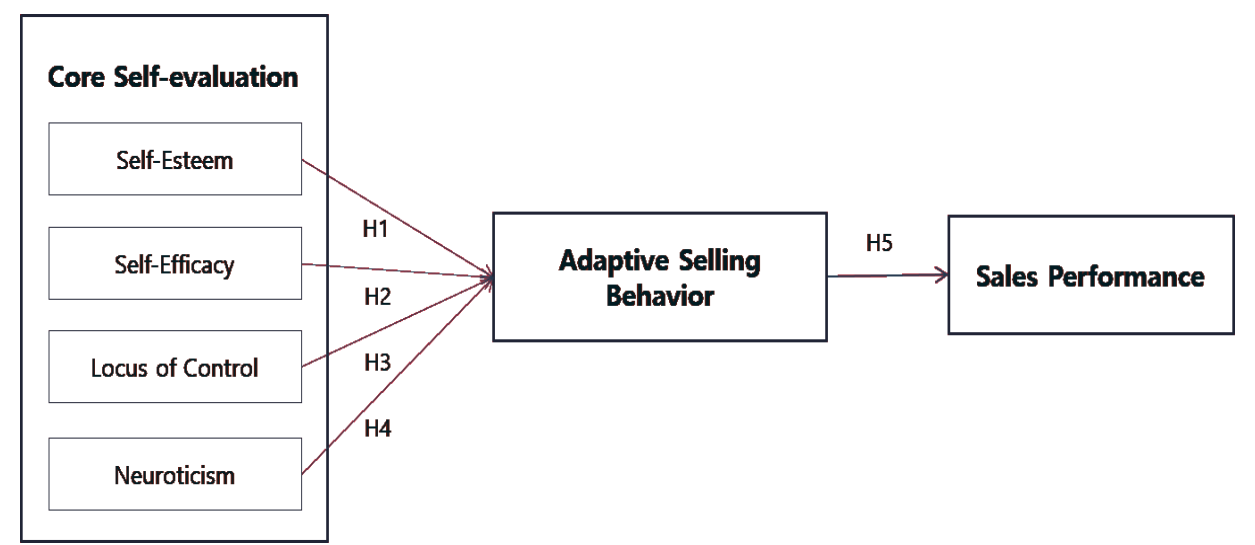

Figure 1: Research model

consisted of core self-evaluation and the four sub-factors of self-esteem, self-efficacy, locus of control, and neuroticism, while adaptive selling behavior was used as the parameter, and sales performance as the dependent variable. This study sought to verify the mediating effect of adaptive selling behavior through path analysis based on structural equation modeling and indirect effect analysis.

\subsection{Operational Definition and Measurement Variables}

This study conducted a survey to collect the data needed to analyze this model. To construct the survey, the items shown in Table 1 below were used based on previous studies, and the operational variables of the survey components were defined. Regarding the operational definitions for the variables used for the survey, "core self-evaluation" refers to the potential disposition and traits of female door-to-door salespeople who use face-to-face channels in evaluating themselves in their sales activities.
Core self-evaluation is comprised of four sub-factors, among which self-esteem refers to the pride and respect of the salespeople for himself or herself, and self-efficacy refers to the sense of satisfaction of the salesperson with their capabilities and value. Locus of control refers to the salesperson's perception of his or her ability to control the situation when facing negative changes, and neuroticism refers to the job satisfaction and positive mindset that salespeople may require while performing sales activities. In addition, adaptive selling behavior is the female salesperson's ability to successfully control uncomfortable situations that may occur with customers at point of contact. Sales performance, the dependent variable, refers to the resulting success factors including the qualitative and quantitative sales performance of female door-to-door salespeople.

These variables were measured on a 5-point Likert scale for the questionnaire, and core self-evaluation was measured through the four items of "self-esteem," "self-efficacy," "locus of control," and "neuroticism," based on the prior research of Judge, Heller, and Klinger (2008). Self-esteem

Table 1: Measurement Variables

\begin{tabular}{|c|c|c|c|c|}
\hline \multicolumn{2}{|c|}{ Factors } & Sub-factors & Items & References \\
\hline \multirow{4}{*}{$\begin{array}{l}\text { Core } \\
\text { self-evaluation }\end{array}$} & Self-esteem & Personal satisfaction, self-merits, differentiated value & 3 & \multirow{4}{*}{$\begin{array}{l}\text { Judge et al. } \\
(2008)\end{array}$} \\
\hline & Self-efficacy & $\begin{array}{l}\text { Goal achievement, effective work solutions, } \\
\text { collaboration ability, and positive attitude }\end{array}$ & 4 & \\
\hline & Locus of control & $\begin{array}{l}\text { Self-determination, whether work can be performed, } \\
\text { level of achievement }\end{array}$ & 3 & \\
\hline & Neuroticism & $\begin{array}{l}\text { Emotional ups and downs, feelings of unhappiness, } \\
\text { degree of worry }\end{array}$ & 3 & \\
\hline \multicolumn{2}{|c|}{ Adaptive selling behavior } & $\begin{array}{l}\text { Changes in sales, learning orientation, goal } \\
\text { orientation }\end{array}$ & 3 & $\begin{array}{l}\text { Bitner, Booms and } \\
\text { Tetreault, (1990) }\end{array}$ \\
\hline \multicolumn{2}{|c|}{ Sales performance } & $\begin{array}{l}\text { Sales performance, new product sales, customer } \\
\text { discovery }\end{array}$ & 3 & $\begin{array}{l}\text { Nikolaou and } \\
\text { Tsaousis (2002) }\end{array}$ \\
\hline
\end{tabular}


consisted of the three items of "personal satisfaction," "selfmerits," and "differentiated value." Self-efficacy consisted of the four items of "goal achievement," "effective work solutions," "collaboration ability," and "positive attitude." Locus of control consisted of the three items of "selfdetermination," "whether work can be performed, "and "level of achievement." And neuroticism consisted of the three items of "emotional ups and downs," "feelings of unhappiness," and "degree of worry." Adaptive selling behavior, the parameter, consisted of the three items of" changes in sales," "learning orientation," and "goal orientation." Based on the previous research of Bitner, Booms, and Tetreault (1990), sales performance, the dependent variable, consisted of the three items of "sales achievement," "new product sales," and "customer discovery," based on Nikolaou and Tsaousis (2002). According to the exploratory factor analysis, the items "level of achievement" of locus of control and "emotional ups and downs' of neuroticism were rejected in the factor analysis and removed from the final analysis.

\section{Results and Discussion}

\subsection{Demographics of the Respondents}

According to the demographic analysis of the survey respondents of female door-to-door salespeople in face-toface channels, $45.7 \%$ of the respondents were in their $50 \mathrm{~s}$, representing the largest group, followed by $30 \mathrm{~s}(24.6 \%)$ and $60 \mathrm{~s}(21.6 \%)$; thus, women in their 30s-60s included the most respondents. In terms of years of sales experience, $24.5 \%$ reported 5 years or less and 24\% reported 15-20 years, indicating that sales experience was evenly distributed. In terms of job rank, director comprised the largest share at $35.6 \%$, followed by branch manager at $27.9 \%$, manager at $19.2 \%$, and department head at $17.3 \%$, showing a large share of high-ranking jobs. In terms of education level, $65.4 \%$ were high school graduates and $22.1 \%$ were technical college graduates, showing that, overall, female door-to-door salespeople did not have a high level of education (Table 2)

Table 2: Demographics of Survey Participants

\begin{tabular}{|c|c|c|c|}
\hline \multicolumn{2}{|r|}{ Category } & Frequency & Ratio \\
\hline \multirow{7}{*}{ Age } & $20 s$ & 1 & 0.5 \\
\hline & $30 s$ & 9 & 4.3 \\
\hline & $40 s$ & 40 & 19.2 \\
\hline & $50 s$ & 95 & 45.7 \\
\hline & $60 \mathrm{~s}$ & 45 & 21.6 \\
\hline & $70 \mathrm{~s}$ & 18 & 8.7 \\
\hline & Total & 208 & 100.0 \\
\hline \multirow{6}{*}{ Sales experience } & 5 years or less & 51 & 24.5 \\
\hline & 5 - 10 years & 48 & 23.1 \\
\hline & $10-15$ years & 39 & 18.8 \\
\hline & 15 - 20 years & 50 & 24.0 \\
\hline & 20 years or more & 20 & 9.6 \\
\hline & Total & 208 & 100.0 \\
\hline \multirow{5}{*}{ Job rank } & Manager & 40 & 19.2 \\
\hline & Middle manager & 36 & 17.3 \\
\hline & Director & 74 & 35.6 \\
\hline & Branch manager & 58 & 27.9 \\
\hline & Total & 208 & 100.0 \\
\hline \multirow{4}{*}{ Education } & High school graduate & 136 & 65.4 \\
\hline & Technical college graduate & 46 & 22.1 \\
\hline & University graduate or above & 26 & 12.5 \\
\hline & Total & 208 & 100.0 \\
\hline
\end{tabular}




\subsection{Analysis Results of Reliability and Validity}

To analyze the reliability and validity of the structural equation measurement model, internal consistency reliability was considered obtained when the composite reliability index was 0.7 or more (Yoon, Kim, \& Eom, 2019). Convergent validity is evaluated by factor loading, Cronbach's $\alpha$, and the composite reliability index; when factor loading is 0.4 or more and Cronbach's $\alpha$ is 0.6 or more and statistically significant, convergent validity is considered to be obtained (Yoon \& Kim, 2019). According to these criteria, all factor loadings were satisfactory at
$0.724-0.929$ (0.7 or higher), and internal reliability was significant with composite reliability at $0.762-0.865$. All $\mathrm{t}$ values were at least 6.0 , indicating statistical significance. The average variance extracted (AVE) ranged from 0.598 to 0.728 , and Cronbach's $\alpha$ ranged from 0.758 to 0.864 , confirming convergent validity.

Moreover, based on the structural model's goodness-offit analysis, $\chi 2$ (p) was 188.53 and $\chi 2 /$ degree of freedom was 1.813. The goodness-of-fit-index (GFI) was 0.904, the normal fit index (NFI) was 0.896, and root mean square error of approximation (RMSEA) was 0.063; as such, the goodness-of-fit measures were all excellent. (Table 3).

Table 3: Results of reliability and convergent validity test

\begin{tabular}{|c|c|c|c|c|c|c|c|c|}
\hline Category & Variable & $\begin{array}{c}\text { Measurement } \\
\text { item }\end{array}$ & $\begin{array}{c}\text { Standardized } \\
\text { factor loading }\end{array}$ & $\begin{array}{l}\text { Standard } \\
\text { error }\end{array}$ & $t$ value & CR & AVE & Cronbach $\alpha$ \\
\hline \multirow{11}{*}{$\begin{array}{l}\text { Independent } \\
\text { Variable }\end{array}$} & \multirow{3}{*}{ Self-esteem } & ses2 & 0.738 & & & \multirow{3}{*}{0.817} & \multirow{3}{*}{0.598} & \multirow{3}{*}{0.815} \\
\hline & & ses3 & 0.792 & 0.106 & $10.22^{* * *}$ & & & \\
\hline & & ses5 & 0.789 & 0.115 & $10.194^{* * *}$ & & & \\
\hline & \multirow{4}{*}{ Self-efficacy } & sef1 & 0.823 & & & \multirow{4}{*}{0.865} & \multirow{4}{*}{0.615} & \multirow{4}{*}{0.864} \\
\hline & & sef2 & 0.782 & 0.072 & $12.276^{* * *}$ & & & \\
\hline & & sef3 & 0.754 & 0.078 & $11.721^{* * *}$ & & & \\
\hline & & sef4 & 0.777 & 0.076 & $12.167^{* * *}$ & & & \\
\hline & \multirow{2}{*}{$\begin{array}{l}\text { Locus of } \\
\text { control }\end{array}$} & Ic1 & 0.770 & & & \multirow{2}{*}{0.841} & \multirow{2}{*}{0.728} & \multirow{2}{*}{0.834} \\
\hline & & Ic2 & 0.929 & 0.139 & $8.635^{* * *}$ & & & \\
\hline & \multirow{2}{*}{ Neuroticism } & ne2 & 0.724 & & & \multirow{2}{*}{0.762} & \multirow{2}{*}{0.617} & \multirow{2}{*}{0.758} \\
\hline & & ne3 & 0.843 & 0.171 & $7.052^{* * *}$ & & & \\
\hline \multirow{3}{*}{ Parameter } & \multirow{3}{*}{$\begin{array}{l}\text { Adaptive } \\
\text { selling }\end{array}$} & asb7 & 0.755 & & & \multirow{3}{*}{0.828} & \multirow{3}{*}{0.616} & \multirow{3}{*}{0.826} \\
\hline & & asb9 & 0.814 & 0.099 & $10.657^{\text {***}}$ & & & \\
\hline & & asb10 & 0.784 & 0.107 & $10.41^{* * *}$ & & & \\
\hline \multirow{3}{*}{$\begin{array}{l}\text { Dependent } \\
\text { Variable }\end{array}$} & \multirow{3}{*}{$\begin{array}{c}\text { Sales } \\
\text { performance }\end{array}$} & sp2 & 0.779 & & & \multirow{3}{*}{0.836} & \multirow{3}{*}{0.629} & \multirow{3}{*}{0.832} \\
\hline & & sp3 & 0.791 & 0.08 & $10.924^{* * *}$ & & & \\
\hline & & sp4 & 0.809 & 0.076 & $11.099^{* * *}$ & & & \\
\hline
\end{tabular}

Table 4: Correlation matrix and AVE

\begin{tabular}{|c|c|c|c|c|c|c|c|}
\hline Category & AVE & Self-esteem & Self-efficacy & $\begin{array}{l}\text { Locus of } \\
\text { control }\end{array}$ & Neuroticism & $\begin{array}{c}\text { Adaptive selling } \\
\text { behavior }\end{array}$ & $\begin{array}{c}\text { Sales } \\
\text { performance }\end{array}$ \\
\hline Self-esteem & 0.598 & 0.773 & & & & & \\
\hline Self-efficacy & 0.615 & $0.681^{* * *}$ & 0.784 & & & & \\
\hline Locus of control & 0.728 & $0.466^{\star \star \star}$ & $0.527^{* * *}$ & 0.853 & & & \\
\hline Neuroticism & 0.617 & $-0.275^{* *}$ & $-0.285^{* *}$ & $-0.343^{* * *}$ & 0.786 & & \\
\hline $\begin{array}{c}\text { Adaptive selling } \\
\text { behavior }\end{array}$ & 0.616 & $0.530^{* * *}$ & $0.561^{* * *}$ & $0.255^{\star *}$ & 0.038 & 0.785 & \\
\hline Sales performance & 0.629 & $0.361^{* * *}$ & $0.547^{* * *}$ & $0.253^{* *}$ & $-0.480^{* * *}$ & $0.393^{* * *}$ & 0.793 \\
\hline
\end{tabular}

Note: The square root of AVE is shown in bold letters. 
For the correlation analysis, according to the criteria presented by Fornell and Larcker (1981), if the square root of the AVE obtained between each latent variable is greater than the correlation coefficient of each latent variable, then discriminant validity between each latent variable can be obtained. According to the analysis of AVE values and correlation coefficients between the latent variables using this criterion (Table 4), the square root of the AVE of each latent variable is larger than the correlation coefficients between the latent variables, and the correlation coefficients were at least 0.7 , confirming discriminant validity.

\subsection{Analysis Results of Structural Model}

According to the structural equation goodness-of-fit analysis shown in Table 5, $\chi 2$ (p) was 239.973 and $\chi 2$ / degree of freedom was 2.222. While GFI was slightly less than 0.9 at 0.881 , AGFI was 0.832 , NFI was 0.868 , and RMSEA was 0.077 ; thus, the majority of the goodness-of-fit component values were excellent, indicating the significance of model fit. CFI, which is not affected by the sample but expresses the model's explanatory power, was 0.921 , and TLI, which determines the explanatory power of the structural model, was 0.901 , indicating the basic model is very fit.

As a result of the path analysis through structural equation modeling, one of the five hypotheses was rejected (Table 6). Among the core self-evaluation factors, self-efficacy showed a positive effect on adaptive selling with a t-value of 3.914 $(\mathrm{p}<0.001)$. Self-esteem also showed a positive effect on adaptive selling at $2.694(\mathrm{p}<0.01)$, and neuroticism was $2.175(\mathrm{p}<0.05)$; as such, these hypotheses were supported. However, locus of control was shown to not affect adaptive selling at -0.551 , and the hypothesis was rejected. Adaptive selling was shown to affect sales performance at 5.044 $(\mathrm{p}<0.001)$, so this hypothesis was supported.

As shown in Table 7, adaptive selling showed a mediating effect on sales performance through the mediators of self-esteem (0.133), self-efficacy (0.201), and neuroticism (0.081), whereas locus of control did not act as a mediator.

Table 5: Model fit indices for the structural models

\begin{tabular}{|c|c|c|c|c|c|c|c|c|c|c|}
\hline Model & $\mathrm{X} 2$ (df) & DF & $\begin{array}{c}\text { X2 / degree } \\
\text { of freedom }\end{array}$ & RMR & GFI & AGFI & NFI & TLI & CFI & RMSEA \\
\hline $\begin{array}{c}\text { Original } \\
\text { model }\end{array}$ & 239.973 & 108 & 2.222 & 0.067 & 0.881 & 0.832 & 0.868 & 0.901 & 0.921 & 0.077 \\
\hline
\end{tabular}

Table 6: Results of hypothesis test

\begin{tabular}{|c|c|c|c|c|}
\hline & Hypothesis (path) & $\begin{array}{c}\text { Path } \\
\text { coefficient }\end{array}$ & t value & Supported/rejected \\
\hline H1 & Self-esteem $\rightarrow$ Adaptive selling & 0.307 & $2.694^{* *}$ & Supported \\
\hline H2 & Self-efficacy $\rightarrow$ Adaptive selling & 0.463 & $3.914^{* * *}$ & Supported \\
\hline H3 & Locus of control $\rightarrow$ Adaptive selling & -0.048 & -0.551 & Rejected \\
\hline H4 & Neuroticism $\rightarrow$ Adaptive selling & 0.187 & $2.175^{*}$ & Supported \\
\hline H5 & Adaptive selling $\rightarrow$ Sales performance & 0.435 & $5.044^{* * *}$ & Supported \\
\hline
\end{tabular}

Note: * $p<0.05,{ }^{* *} p<0.01,{ }^{* *} p<0.001$

Table 7: Indirect Effects

\begin{tabular}{|c|c|c|}
\hline Hypothesis $($ path) & Indirect effect & p value \\
\hline Self-esteem $\rightarrow$ Adaptive selling $\rightarrow$ Sales performance & $0.133^{*}$ & 0.014 \\
\hline Self-efficacy $\rightarrow$ Adaptive selling $\rightarrow$ Sales performance & $0.201^{* *}$ & 0.010 \\
\hline Locus of control $\rightarrow$ Adaptive selling $\rightarrow$ Sales performance & -0.021 & 0.529 \\
\hline Neuroticism $\rightarrow$ Adaptive selling $\rightarrow$ Sales performance & $0.081^{* *}$ & 0.010 \\
\hline
\end{tabular}

Note: * $p<0.05,{ }^{* *} p<0.01,{ }^{* * *} p<0.001$ 


\section{Conclusions}

To suggest implications for enhancing the sales performance and sales capability of female door-to-door salespeople, this study sought to empirically highlight the relationship between adaptive selling and core self-evaluation factors required by salespeople in a changing face-to-face sales channel environment. Three implications were derived based on the analysis results. First, self-esteem, self-efficacy, and neuroticism, three of the four core self-evaluation factors for female salespeople, had a positive effect on sales performance through the mediation of adaptive selling. More specifically, self-efficacy was shown to be the most important factor, indicating that higher self-efficacy of female door-todoor salespeople can strengthen their problem-solving skills and enhance their sales capability in various situations at a customer's point of contact.

Second, conversely, locus of control did not affect adaptive selling or sales performance through the mediation of adaptive selling. This confirms that the salesperson's internal judgment of his or her self-determination, or ability to perform work, is not reflected in the field and does not directly affect sales capability. Third, adaptive selling served a mediating role for the core self-evaluation factors and sales performance, and the improvement of adaptive selling factors directly affected sales performance. These findings reflect those of previous studies (Ashforth \& Humphrey, 1993; Diefendorff, Croyle, \& Gosserand, 2005), confirming that these same results apply to the sales performance of door-to-door salespeople based on face-to-face channels, especially female door-to-door salespeople.

Accordingly, while various studies have investigated sales capability, this study is significant in that it highlights the relationship with sales capability and performance required by female salespeople, who also represent the core workforce of door-to-door salespeople based on face-toface channels. While previous studies (Frank \& Park, 2006; Grandey, 2003) emphasized the importance of adaptive selling behavior, this study is meaningful in that it presents empirical results on whether these findings apply to doorto-door sales as well. From a practical perspective, there is some prejudice that female salespeople may be weak in their field-based sales capabilities and emotional approach.

However, according to this study's results, female salespeople demonstrated increased field sales capability when their self-efficacy (e.g., self-merits or differentiated value) improved. As this has a positive impact on sales performance, companies that use face-to-face channels may want to require a training and management system that focuses on strengthening their employees' self-efficacy. In particular, while training and management systems for doorto-door salespeople, which have traditionally centered around women, have prioritized emotional or human approaches, companies must also consider a managerial approach that enhances salespeople's confidence and self-esteem.

Additionally, as shown in previous studies, face-to-face service workers show lower customer orientation and higher turnover intention when experiencing emotional exhaustion (Karatepe, 2009; Kang, Hur, \& Kim, 2018) as such, in terms of job performance, it is important to provide female doorto-door salespeople with a system and environment for learning-oriented motivation to work through systematic selection and management. In particular, sales performance can be improved more efficiently by clearly analyzing the causes of job stress and decreases in self-efficacy, and using the results to strengthen work capability at the point of contact with customers, and teach response techniques through management.

Finally, adaptive selling behavior is a sales strategy to provide appropriate services to meet customer needs and improve satisfaction; accordingly, the market orientation and customer orientation of salespeople must be improved. In the past, door-to-door sales used the tactic of forcing sales based on in-depth product understanding, but today, companies must enhance customer-focused sales activities through adaptive selling behaviors. For this reason, companies need to provide training and learning programs to cultivate various sales skills and the ability to judge the characteristics of the customer and the situation, as well as drive system-wide sales capabilities at the organizational level, which deviates from past practices of depending more on individual sales capabilities.

Despite these research implications, this study has the following limitations. First, this study limited the investigation of face-to-face channel sales to wellness products, such as health food and cosmetics. As such, there are limitations in generalizing the results to other face-toface channel sales. In the future, detailed studies should be performed to compare and analyze industries that use more varied face-to-face channels, and empirical studies are needed to comprehensively examine different forms of door-to-door sales across diverse industries to present empirical results on female door-to-door salespersons' sales capabilities that can be generalized. Second, by selecting only female door-todoor salespeople as research subjects, there are limitations in suggesting the characteristics of female salespeople through comparisons with male door-to-door salespeople. Hence, future studies should perform comparative analyses of both groups of female and male salespeople. Third, as the analysis variables, this study used core self-evaluation factors and adaptive selling factors, which are generally discussed in the sales field. However, it may also be necessary to design variables for core self-evaluation and adaptive selling factors that consider the characteristics of face-to-face channels, as well as the cultural characteristics of door-to-door sales organizations. Accordingly, there is an opportunity for 
future studies to identify and develop differentiated core self-evaluation factors and adaptive selling factors based on qualitative research methodology, and through this, to conduct more advanced investigations on the relationship with sales performance focusing on door-to-door sales.

\section{References}

Adelmann, P. K. (1995). Emotional labor as a potential source of job stress. In S. L. Sauter \& L. R. Murphy (Eds.), Organizational risk factors for job stress (pp.371-381). New York, NY: American Psychological Association.

Anderson, E., \& Oliver, R. L. (1987). Perspectives on behaviorbased versus outcome-based salesforce control systems. Journal of Marketing, 51(4), 76-88.

Arfah, A., \& Putra, A.H.P.K. (2019). Analysis of productivity of distribution of female workers in FB's industries. Journal of Distribution Sciences, 17(3). 31-39.

Ashforth, B. E., \& Humphrey, R. H. (1993). Emotional labour in service roles: The influence of identity. Academy of Management Review, 18(1), 88-115.

Baldauf, A., \& Cravens, D. W. (2002). The effect of moderators on the salesperson behavior performance and salesperson outcome performance and sales organization effectiveness relationships. European Journal of Marketing, 36(11/12), 1367-1388.

Bitner, M. J., Booms, B. H., \& Tetreault, M. S. (1990). The service encounter: diagnosing favorable and unfavorable incidents. Journal of Marketing, 54(1), 71-84.

Bono, J. E., \& Judge, T. A. (2003). Core self-evaluations: A review of the trait and its role in job satisfaction and job performance. European Journal of Personality, 17(S1), 5-18.

Boorom, M. L., Goolsby, J. R., \& Ramsey, R. P. (1998). Relational communication traits and their effect on adaptiveness and sales performance. Journal of the Academy of Marketing Science, 26(1), 16-30.

Bray, D. W. (1994). Personnel-centered organizational diagnosis. In A. Howard, The professional practice series. Diagnosis for organizational change: Methods and models (pp.152-171). New York, NY: Guilford Press.

Brown, S. P., Mowen, J. C., Donavan, D. T., \& Licata, J. W. (2002). The customer orientation of service workers: personality trait determinants and effects on self and supervisor ratings. Journal of Marketing Research, 39(1), 110-119.

Bucklin, L. P., \& Sengupta, S. (1993). Organizing successful comarketing alliances. Journal of Marketing, 57(2), 32-46.

Burnham, T. A., Frels, J. K., \& Vijay, M. (2003). Consumer Switching Costs: A Typology, Antecedents and Consequences. Journal of Academy of Marketing Science, 31(2), 109-126

Chakrabarty, S., Brown, G., \& Widing, R. E. (2013). Distinguishing between the roles of customer-oriented selling and adaptive selling in managing dysfunctional conflict in buyer-seller relationships. Journal of Personal Selling \& Sales Management, 33(3), 245-260.
Chakrabarty, S., Brown, G., Widing, R. E., \& Taylor, R. D. (2004). Analysis and recommendations for the alternative measures of adaptive selling. Journal of Personal Selling \& Sales Management, 24(2), 125-133.

Cordes, C. L., \& Dougherty, T. W. (1993). A review and an integration of research on job burnout. Academy of Management Review, 18(4), 621-656.

Diefendorff, J. M., Croyle, M. H., \& Gosserand, R. H. (2005). The dimensionality and antecedents of emotional labor strategies. Journal of Vocational Behavior, 66(2), 339-357.

Fornell, C., \& Larcker, D. F. (1981). Structural equation models with unobservable variables and measurement error: Algebra and statistics. Journal of Marketing Research, 18(3), 328-388.

Franke, G. R., \& Park, J. E. (2006). Salesperson adaptive selling behavior and customer orientation. Journal of Consumer Research, 21(1), 1-31.

Grandey, A. A. (2003). When "The show must go on": surface acting and deep acting as determinants of emotional exhaustion and peer-rated service delivery. Academy of Management Journal, 46(1), 86-96.

Hobfoll, S. E., Johnson, R. J., Ennis, N., \& Jackson, A. P. (2003). Resource loss, resource gain, and emotional outcomes among inner city women. Journal of Personality and Social Psychology, 84(3), 632-643.

Homburg, C., Wieseke, J., \& Bornemann, T. (2009). Implementing the marketing concept at the employee-customer interface: The role of customer need knowledge. Journal of Marketing, 73(4), 64-81.

Humphrey, R. H., \& Ashforth, B. (1994). Cognitive scripts and prototypes in service encounters. Advances in services marketing and management, 3(C), 175-199.

Jaramillo, F., Ladik, D. M., Marshall, G. W., \& Mulki, J. P. (2007). A meta-analysis of the relationship between sales orientation customer orientation (SOCO) and salesperson job performance. Journal of Business and Industrial Marketing, 22(5), 302-310.

Jeong, Y., Ahn, S., \& Lee, H. (2017). Differential effect of control mechanism toward salesperson on SOCO behaviors and sales performance in pharmaceutical distribution channel. Distribution Research, 22(1), 69-91.

Jones, M. A., Mothersbaugh, D. L., \& Beatty, S. E. (2002). Why customers stay: measuring the underlying dimensions of services switching costs and managing their differential strategic outcomes. Journal of Business Research, 55(6), 441-450.

Judge, T. A., Erez, A., Bono, J. E., \& Thoresen, C. J. (2003). The core self-evaluations scale: Development of a measure. Personnel Psychology, 56(2), 303-331.

Judge, T. A., Heller, D., \& Klinger, R. (2008). The dispositional sources of job satisfaction: A comparative test. Applied Psychology: An International Review, 57(1), 361-372.

Judge, T. A., Locke, E. A., \& Durham, C. C. (1997). The dispositional causes of job satisfaction: A core evaluations approach. Research in Organizational Behavior, 19(1), 151-188. 
Kang, S. H., Hur, W. M., \& Kim, M. S. (2018). The effects of female service managers' self-determined motivations on job performance. Journal of Distribution Sciences, 16(2), 69-80.

Karatepe, O. M., \& Karatepe, T. (2009). Role stress, emotional exhaustion, and turnover intentions: does organizational tenure in hotels matter? Journal of Human Resources in Hospitality \& Tourism, 9(1), 1-16.

Keillor, B. D., Parker, R. S., \& Pettijohn, C. E. (2000). RelationshipOriented Characteristics and Individual Salesperson Performance. Journal of Business \& Industrial Marketing, 15(1), 7-22.

Kelley, S. W. (1992). Developing customer orientation among service employees. Journal of the Academy of Marketing Science, 20(1), 27-36.

Kim, N., Lee, H., \& Lee, D. (2009). The impacts of salesperson's relationship beliefs on adaptive selling and sales performance: Moderating effect of insurance salesperson's career. AsiaPacific Journal of Business \& Commerce, 1(2), 151-171.

Kim, S. (2007). A study on relationship of salesperson's attachment tendency, relationship beliefs, and adaptive selling. Marketing Research, 22(2), 135-175.

Kohli, A. K., \& Jaworski, B. J. (1994). The influence of coworker feedback on salespeople. Journal of Marketing, 58(4), 82-94.

Kotler P., Armstrong G., Saunders J., \& Wong V. (1996). Principles of Marketing, the European Edition. London, England: Prentice Hall.

Kwak, H., Anderson, R. E., Leigh, T. W., \& Bonifield, S. D. (2019). Impact of salesperson macro-adaptive selling strategy on job performance and satisfaction. Journal of Business Research, 94, 42-55.

Lee, I., \& Ji, S. (2014). Effects of control types on adaptive selling behavior and sales performance. Journal of Distribution and Management Research, 17(3), 91-98.

Lee, S. S. (2014). A comparative study on consumer's perception, satisfaction, repurchase intentions between door-to-door marketing and multi-level marketing. Korean Society of Consumer Studies, 25(2). 32-45.

Lee, W. S., \& Kim, B. Y. (2019). The effects of career orientations on entrepreneurial satisfaction and business sustainability. Journal of Asian Finance, Economics and Business, 6(4), 235248. https://doi.org/10.13106/jafeb.2019.vol6.no4.235

Narver, J. C., \& Slater, S. F. (1990). The effect of a marketing orientation on business profitability. Journal of Marketing, 54(4), 20-35.

Nguyen, N. D. P., \& Nguyen, T. D. (2017). The effect of countryof-origin on customer purchase intention: A study of functional products in Vietnam. Journal of Asian Finance, Economics and Business, 4(3), 75-84. http://dx.doi.org/10.13106/jafeb.2017. vol4.no3.75

Nikolaou, I., \& Tsaousis, I. (2002). Emotional intelligence in the workplace: Exploring its effects on occupational stress and organizational commitment. International Journal of Organizational Analysis, 10(4), 327-342.
Oke, J. B., Cohen, J. G., Carr, M., Cromer, J., Dingizian, A., Harris, F. H., \& Miller, J. (1995). The Keck low-resolution imaging spectrometer. Publications of the Astronomical Society of the Pacific, 107(710), 375-385.

Parasuraman, A. (1987). Customer-oriented corporate cultures are crucial to services marketing success. Journal of Services Marketing, 1(1), 39-46.

Park, J. E., \& Deitz, G. D. (2006). The effect of working relationship quality on salesperson performance and job satisfaction: Adaptive selling behavior in Korean automobile sales representatives. Journal of Business Research, 59(2), 204-213.

Peppard, J. (2000). Customer relationship management (CRM) in financial services. European Management Journal, 18(3), 312327.

Rust, R. T., Zahorik, A. J., \& Keiningham, T. L. (1995). Return on quality (ROQ): Making service quality financially accountable. Journal of Marketing, 59(2), 58-70.

Saxe, R., \& Weitz, B. A. (1982). The SOCO scale: A measure of the customer orientation of salespeople. Journal of Marketing Research, 19(3), 343-351.

Shapiro, B. P. (1988). What the hell is market oriented? Harvard Business Review, 66, 119-125.

Shaw, G., Brown, R., \& Bromiley, P. (1998). Strategic stories: How $3 \mathrm{M}$ is rewriting business planning. Harvard Business Review, 76(3), 41-49.

Solomon, M. R., Surprenant, C., Czepiel, J. A., \& Gutman, E. G. (1985). A role theory perspective on dyadic interactions: the service encounter. Journal of Marketing, 49(1), 99-111.

Spiro, R. L., \& Weitz, B. A. (1990). Adaptive selling: conceptualization, measurement and nomological validity. Journal of Marketing Research, 27(1), 61-69.

Stock, R. M., \& Hoyer, W. D. (2005). An attitude-behavior model of salespeople's customer orientation. Journal of the Academy of Marketing Science, 33(4), 536-552.

Swan, J. E., \& Nolan, J. J. (1985). Gaining customer trust: a conceptual guide for the salesperson. Journal of Personal Selling \& Sales Management, 5(2), 39-48.

Swan, J. E., Bowers, M. R., \& Richardson, L. D. (1999). customer trust in the salesperson: An integrative review and meta-analysis of the empirical literature. Journal of Business Research, 44(2), 93-107.

Szymanski, D. M. (1988). Determinants of selling effectiveness: the importance of declarative knowledge to the personal selling concept. Journal of Marketing, 52(1), 64-77.

Taylor, S. E. (1983). Adjustment to threatening events: A theory of cognitive adaptation. American Psychologist, 38(11), 11611173.

Vink, J., \& Verbeke, W. (1993). Adaptive selling and organizational characteristics: Suggestions for future research. Journal of Personal Selling \& Sales Management, 13(1), 15-23.

Walker, O. C. Jr., Churchill, G. A. Jr., \& Ford, N. M. (1977). Motivation and performance in industrial selling: present 
knowledge and needed research. Journal of Marketing Research, 14(2), 156-168.

Wanberg, C. R., \& Banas, J. T. (2000). Predictors and outcomes of openness to changes in a reorganizing workplace. Journal of Applied Psychology, 85(1), 132-142.

Weitz, B. A. (1981). Effectiveness in sales interactions: a contingency framework. Journal of Marketing, 45(1), 85-103.

Weitz, B. A., Sujan, H., \& Sujan, M. (1986). Knowledge, motivation, and adaptive behavior: A framework for improving selling effectiveness. Journal of Marketing, 50(4), 174-191.
Yeo, C., Cho, Y., \& Lee, H. (2017). The Effect of sales people's organizational identification on customer-oriented selling and performance: Focused on moderating effect of employment status. Journal of Marketing Studies, 25(1), 111-129.

Yoon, D. W., \& Kim, B. Y. (2019). The effects of core selfevaluation factors of female salesperson on sales performance. Journal of Distribution Sciences, 17(11), 5-15.

Yoon, K. H., Kim, B. Y., \& Eom J. G. (2019). The effects of job crafting on career success of multinational corporations' employee. Journal of Asian Finance, Economics and Business, 6(4), 213-225. https://doi.org/10.13106/jafeb.2019.vol6.no4.213 